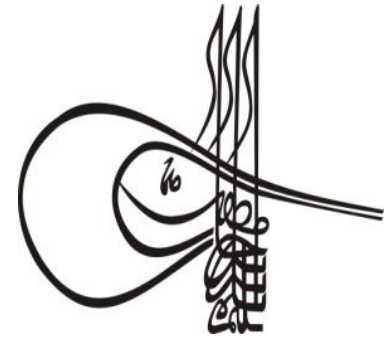

\author{
Research Article / Araştırma Makalesi \\ Article Info/Makale Bilgisi
}

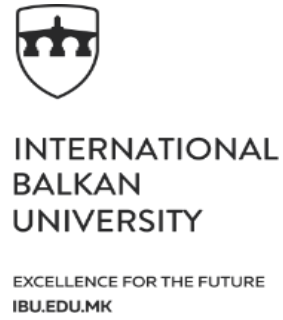

IBU.EDU.MK

Received/Geliş: 02.09.2019

\Accepted/Kabul: 20.12.2019

This article was checked by iThenticate.

\title{
MÜBTEDÂ’NIN NEKRE OLARAK GELDİĞİ DURUMLAR VE KUR'ÂN'DAKİ UYGULAMALARI
}

\author{
Hamit SALIHHOĞLU*
}

\begin{abstract}
öz
İsim cümlesinin iki temel unsuru bulunmaktadır. Bu unsurlardan biri mübtedâ diğeri ise haberdir. Dilciler tarafından birbirinden farklı şekillerde tanımlanmış olan mübtedâ, Sîbeveyhi tarafından "bir ifadenin üzerine bina edilmesi için kendisiyle başlatılan isim" olarak tarif edilmiştir. Mübtedâ cümlede müsnedün ileyh konumunda olan bir unsur olduğu için onun ma'rife olması gerekir. Çünkü belli olmayan bir şey hakkında hüküm vermek muhataba herhangi bir fayda sağlamayacağı gibi bir şey de ifade etmez. Ancak bazı durumlarda mübtedâ nekre olarak da gelebilir. Nahiv kaynaklarında mütekaddimun ile müteahhirun olarak ifade edilen nahiv âlimlerinin bu konuya dair yaklașımları birbirinden farklı olmuștur. Nitekim mütekaddimun olarak geçen âlimler, fayda vermesi durumunda mübtedâ'nın nekre olarak gelebileceğini zikretmiş fakat onun hangi durum ve sebeplerle fayda vereceği konusunda bazı örnekler dısıında herhangi bir bilgi vermemişlerdir. Kaynaklarda müteahhirun olarak geçinen âlimler ise, mübtedâ'nın hangi sebeplerle nekre olarak gelebileceği hususuyla ilgili geniş bilgiler vermişlerdir. Fakat onlar da söz konusu sebeplerin sayısı hususunda kendi aralarında ihtilaf etmisslerdir. Nitekim onlardan bazıları, bu sebepleri umum ve husus ile ifade edilen iki ana sebebe hasrederken, onlardan çoğu ise söz konusu sebepleri belli sayılarla ifade etmiss ve onları teker teker ele alıp incelemisslerdir. Örneğin İbn Mâlik bu sebeplerin sayısını altı, İbn Hişâm on, Sabbân on beş, İbn 'Akil yirmi dört, Ebû Hayyân yirmi yedi, Suyûtî otuz bir, İbnü'n-Nehhâs otuz iki, el-'Unnabî ise, kırk iki olarak vermiştir.
\end{abstract}

Kur'ân'nın muhtelif yerlerinde değişik sebeplerle mübtedâ'nın nekre olarak geçtiği görülmektedir. Ancak nahiv kaynaklarında yer alan 
söz konusu sebeplerden sadece belli bir kısmının Kur'ân'da geçtiği müşahede edilmektedir.

Anahtar Kelimeler: Mübtedâ, Nekre, Kur'ân-1 Kerim, sebep, caiz.

\title{
SITUATIONS THAT FIRST PART IN SENTENCE CAMES AS INDEFINITE AND ITS APPLICATIONS IN THE KORAN
}

\begin{abstract}
The noun clause has two main factors. One of them is subject and the other one is the predicate. The first part in sentence which has been defined in the different ways from each other by the linguists were described as "the noun which is started with itself in order that it is created on a statement" by Sîbeveyhi. As the first part is a factor in the position of a subject in a sentence, it should be definite. Because it does not provide any benefit and state anything for the acceptor to adjudicate on indefinite thing. However, the first part in sentence can come as indefinite in some cases. The scholars of syntax that they are mentioned as predecessor and successor in the syntax sources had the different approaches on this matter. So the scholars who were mentioned as predecessor mentioned that the first part in sentence can be as indefinite if it is beneficial but they did not give any information except some samples about what the situations and reasons it will provide benefit. The scholars who were mentioned as the successor in the sources provided full information about what the reasons first part in sentence can come as indefinite. However, they had conflict among themselves about the number of aforementioned reasons. Some of them devoted those reasons to two main reasons which are stated as general and matter while most of them stated the aforementionedreasons with the certain numbers and theyconsidered and reviewed them one-byone. For example, İbn Mâlik gave the number of thosereasons as six,İbn Hişâm gave as ten, Sabbân gave as fifteen, İbn 'Akil gave as twenty four, Ebû Hayyân gave as twenty seven, Suyûtî gave as thirty one, İbnü'nNehhâs gave as thirty two, and el-'Unnabî gave as fourty two.

It is seen that the first part in sentence is indefinite due to the various reasons in some parts of The Koran. However, it is observed that a certain part of aforementioned reasons in the syntax reasons is seen in The Koran.
\end{abstract}

\section{STRUCTURED ABSTRACT}

In our study, subject's dictionary and term meanings will be given and the outstanding syntax scholars' descriptions related to it will be mentioned, and those scholars' views relatedin which situations and with what kind of reasons the subject can come as an uncertain will be widely considered and reviewed. Moreover, it will be considered and analyzed with the samples about what the reasons the subject came as uncertain in The Quran.

The noun clause has two main factors. One of them is subject and the other one is the predicate. The linguists brought the different

Turkish Studies - Language and Literature

Volume 14 Issue 4, 2019 
descriptions for the subject. While some linguists prioritized the subject's wording and its array form in the sentence, some of them emphasized on its duty in the sentence in their descriptions. Some linguists considered the sefactors in their descriptions. Sîbeveyhi (d. $180 / 796)$ who was accepted as an authority in the languagefielddefined the subject as "a noun which is started with itself in order that it can be founded on a statement". One of the factorsdistinguishing the subject and predicate from each other is the certainness and uncertainness. As the subject is a factor on the subjectposition in a sentence, it should be certain. Becauseit doesn't mean anything as it will not provide anybenefits to the addressee to adjudicateon an uncertain thing. As the predicate is a factor on the predicateposition in the sentence, it should be uncertain. However, thesubject can come as uncertain. Whenthesereasons in the syntaxresourcesare considered,asa part of them is associateddirectly with the uncertainsubject, the other part is connected with the words comingas prior to the subject, and the rest is related to the words following it. Thesereasons became the disputeissueamong the scholars of syntax in terms of their numbers and meanings. The prominent scholars including Sîbeveyhi and İbn Sarrâc did not provide any condition sexcept that the subject gives benefit in order to be uncertain and did not provide any information on which situations it can benefit. Even if the following scholars gave information related to those reasons, theywere not in accord on the number of afore mentioned reasons. Some of them devoted those reasons to two main reasons which are stated as general and matter while most of them stated the afore mentioned reasons with the certain numbers and they considered and reviewed them one-by-one. For example, İbn Mâlik gave the number of thosereasons as six,İbn Hişâm gave as ten, Sabbân gave as fifteen, İbn 'Akil gave as twenty four, Ebû Hayyân gave as twenty seven, Suyûtî gave as thirty one, İbnü'n-Nehhâs gave as thirty two, and el-'Unnabî gave as fourty two.

When the uncertain one comesas following some noun and letters in Arabic language, these nouns and letters get it near to the certain one and makes it beneficial one. Thus, they cause to make the uncertain noun following them come as subject. The situations that the uncertain noun comes after these reasons are such as ; uncertain, inquiry preposition, benefit prepositions, need, izâel-fücâiyye, vâv'u'lhâliyye, fâu'l-cezâiyye, lâm'iibtidâyye, the assigned preposition, innein answer to beneficial one, adverb, car and mecrur or when it comesafter the predicate as the sentence, after its own predicate'sma'mûl. When the uncertain one is referred to any subjects or the certain one is referred to the subject, when the uncertain one comes as an answer to the question or an answer to the question which is asked with hemze and en or it is used in the purpose of an objection.

In Arabic language, some noun and letters following the uncertain oneget the uncertain one near to the certain one and make it beneficial. Thus, afore mentioned nouns and letters cause that the coming of uncertain one preceding them as subject becomes lawful. The parts that the uncertain one comes as a certain one following the afore mentioned nouns and letters are such as; when the uncertain one is mixed with an explicit or inevitable adjective, substitutes of the mixed one, is determined with the moral or literal relation, an uncertain one which is

\section{Turkish Studies - Language and Literature}

Volume 14 Issue 4, 2019 
lawful to be subjectis directed towards an uncertain one also, the predicate of uncertain one is a conditional one.

In Arabic language, sone uncertain ones give out a general or matter or include some properties in the certain words. The uncertain ones containing these properties can come as certain as theygivebenefit to the addressee. The uncertain ones containing these properties are such as ; one coming in the detailed purposes, coming near to the certain one as it doesn't accept the el-afformative, one expressing the general, one that a definite figure is demanded from it, one that a definite figure is not demanded from it, uncertain noun, interrogation noun, conditional noun, kem giving the predicate, mâ giving the astonishment, one giving the practice, one giving the astonishment, a noun giving the prayer, when the uncertain one is a reduction noun, a word giving imperative or in the meaning of verb, is in another meaning of the sentence beginning with the uncertain one, the predicate of uncertain one states an extraordinary meaning.

When the afore mentioned reasons in The Quran is considered, it is seen that only a definite part of reasons making the subject come as uncertain in a lawful way is available. Some reasons which are determined in The Quran are such as; when the uncertain one is mixed with an adjective, is a word in the meaning of factor or prayer, a word informing the general one or coming in the detailed purposes, is an answer for the inevitable question, is a subject to uncertain one or the uncertain one is referred to the subject, the uncertain one comes after the benefit preposition, interrogation preposition, izâel-fücâiyevâv'u'lhâliyye and levlâ, the uncertain one comes after the adverb, car and mecrurpredicate, when the uncertain noun is a word which gives the conditional preposition, the determined noun, the astonish meaning

Keywords: Subject, Indefinite, Syntax, Koran, reason.

\section{Giriş}

İsim cümlesinin iki temel unsuru bulunmaktadır. Bu unsurlardan biri mübtedâ diğeri ise haberdir. Bu her iki unsurun da cümlede üstlendikleri görevlerinden ötürü kendine özgü bazı özellikleri bulunmaktadır. Mübtedâ ve haberi birbirinden ayıran hususlardan biri ma'rifelik ve nekrelik olgusudur. Zira mübtedâ'da asıl olan ma 'rifelik haberde ise asıl olan nekreliktir. Cümlede mübtedâ müsnedün ileyh konumunda olan bir unsur olduğu için onun ma'rife olması gerekir. Çünkü belli olmayan bir şey hakkında hüküm vermek muhataba herhangi bir fayda sağlamayacağ1 gibi hiç bir şey de ifade etmez. Haber ise cümlede müsned konumunda olan bir unsur olması nedeniyle onun nekre olarak gelmesi daha uygun görülmüştür. Bu nedenle bir ma'rife ile bir nekre cümlede bir arada bulunduğu zaman tereddüt etmeden ma'rife olan ismin mübtedâ, nekre olan ismin ise haber olduğunu belirtmek gerekir. Ancak bazı durumlarda mübtedâ nekre olarak da gelebilir. Fakat mübtedâ'nın nekre olarak gelebilmesi için onun mutlaka fayda veren bir kelime olması gerekir. Bu hususla ilgili nahiv âlimleri tarafından birbirinden farklı iki yaklaşım biçimi diğer bir tabirle iki görüş öne çıkmıştır. Nahiv kaynaklarında mütekaddimun olarak geçen âlimler, fayda vermesi koşuluyla mübtedâ'nın nekre olarak gelebileceğini belirtmiş, fakat onun hangi durum ve sebeplerle fayda vereceği hususunda bazı örnekler haricinde herhangi bir bilgi vermemişlerdir. Kaynaklarda müteahhirun olarak geçen âlimler ise, mübtedâ'nın hangi durumlarda ve ne tür sebeplerle nekre olarak gelebileceği konusunda geniş bilgiler vermişlerdir. Fakat onlar da 
söz konusu sebeplerin sayısı hususunda ittifak etmemiş ve bu nedenle birbirinden farklı sayılar öne sürmüşlerdir (İbn Hişâm, 1985: 608; es-Suyûtî, II, 109; Tekin, 2018: 313-323).

Kur'ân'da mübtedâ'nın nekre olarak geldiği örneklere gelince, Kur'ân'nın muhtelif yerlerinde mübtedâ'nın nekre olarak geçtiği bilinmektedir. Fakat nahiv âlimlerinin mübtedâ'nın nekre olarak gelebilmesi için zikrettikleri şart ve sebeplerden sadece belli bir kısmının Kur'ân'da geçtiği görülmektedir.

Bu çalışmada mübtedâ'nın lügat ve terim anlamıyla birlikte seçkin nahiv âlimlerinin ona getirdikleri tanımlar zikredilecek ve bu âlimlerin mübtedâ'nın hangi durumlarda ve ne tür sebeplerle nekre olarak gelebileceği hususuyla ilgili görüşleri geniş bir şekilde ele alınıp incelenecektir. Ayrıca Kur'ân'da mübtedâ'nın hangi sebeplerle nekre olarak geldiği örnekleriyle birlikte ele alınıp tahlil edilecektir.

\section{Mübtedâ}

\subsection{Mübtedâ'nın Sözlük Anlamı}

مُبْتَد (mübtedâ), ifti’âl babından olan kendisiyle başladığı şey anlamına gelen bir kelimedir. مُبْتَّاً kelimesinin kendisinden türemiş olduğu

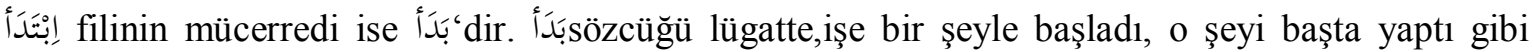
anlamlara gelmektedir(er-Râzî, 1999: I, 30). Bu sözcüğün mastarı olan البَدْد kelimesi, bir şeyi başta yapmak manasına gelirken, onun türevlerinden olan المُبدِيى lafzı ise Allâh'ın isimlerinden biri olup eşyayı maddesiz, örneksiz olarak ilk yaratan ve kâinatı yoktan var eden anlamına gelmektedir. filinden türetilen diğer bir kelime de البَدِيءُ sözcüğüdür. Bu sözcük, ilk ve birinci olan anlamını

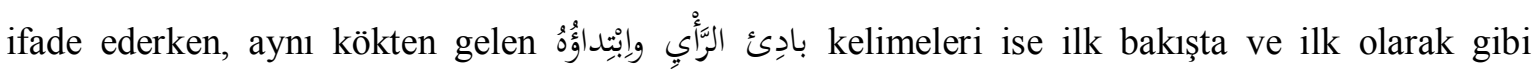
manalara gelmektedir (el-Cevherî,1987: I, 35; er-Râzî, 1999: I, 30).

\subsection{Mübtedâ'nın Terim Anlamı}

Dilciler, mübtedâ için birbirinden farklı tanımlar getirmişlerdir. Nitekim bazı dilciler, tanımlarında mübtedâ’nın lafzına ve cümledeki diziliş şekline öncelik verirken, bazıları da onun cümlede üstlendiği göreve vurgu yapmışlardır. Bazı dilciler ise, tanımlarında bu her iki hususu da dikkate almıştır. Nitekim dilcilerden Sîbeveyhi (ö. 180/796), mübtedâyı, "bir ifadenin üzerine bina edilmesi için kendisiyle bașlatılan isim" (Sîbeveyhi, 1988: II, 126) seklinde tanımlarken, el-Cürcânî (ö. 816/1413) onu, "isnâd için ismi, lafzî âmillerden soyutlamak" șeklinde tarif etmiștir (Cürcânî,1983: I, 7).ez-Zemahşerî (ö. 538/1144) ise mübtedâ'y1, "isnâd için soyutlanmış isim" olarak tanımlamıştır (ez-Zemahşerî, 1993: 43).

\subsection{Mübtedâ'nın Nekreliği}

Mübtedâ'da as1l olan ma 'rifeliktir. Zira mübtedâ cümlede müsnedün ileyh ve mahkumun aleyh yani kendisi hakkında hüküm verilen ve yargıda bulunan unsurdur. Bu nedenle onun ma'rife olması gerekir. Çünkü belli olmayan bir şey hakkında hüküm vermek muhataba herhangi bir fayda sağlamayacağı gibi hiç bir şey de ifade etmemektedir (İbn Mâlik, 1990: I, 289; İbn Yaîş, 200: I, 224; es-Suyûtî, I, 380). Ancak bazı durumlarda mübtedâ nekre olarak gelebilmektedir. Mübtedâ'nın nekre olarak geldiği bu durumlar nahiv kaynaklarında مُسَوّغاتُ الإبتِّداءِ بِالنَّكِِة (nekreyle ibtidâ etmeyi câiz kılan sebepler) olarak ifade edilmektedir. Fakat nahiv âlimlerinin bu konuya dair yaklaşımları ve onu ele alış biçimleri birbirinden farklı olmuştur. Nitekim mütekaddimun olarak

\section{Turkish Studies - Language and Literature}

Volume 14 Issue 4, 2019 
bilinen âlimler, mübtedâ'nın ma'rife olması gerektiğini ifade ettikten sonra fayda vermesi koşuluyla onun nekre olarak da gelebileceğini zikretmişlerdir. Fakat onlar, mübtedâ'nın hangi durum veya şartlarda fayda verebileceği hususunda bilgi vermemişlerdir (İbn Hişâm, 1985: 608).

$\mathrm{Bu}$ âlimlerden biri Sîbeveyhi'dir. Nitekim o, mübtedâ'nın ma ‘rife olması gerektiğini belirttikten sonra fayda vermesi koşuluyla onun nekre olarak da gelebileceğini zikretmiştir (Sîbeveyhi, 1988: I, 329).el-Mekûdî (ö. 807/1405), Sîbeveyhi'nin, mübtedâ'nın nekre olarak gelebilmesi için fayda vermesi koşulu dışında her hangi bir şart koşmadığını kaydetmiştir (elMekûdî, 2005: 50). İbn Serrâc (ö. 316/929) da, mübtedâ'nın ma'rife veya bir sifatla marifeye yakınlaşmış bir nekre olması gerektiğini beyan ettikten sonra bu konuda esas olanın cümlenin fayda verip vermemesi hususu olduğunu belirtmiştir. Nitekim o, mübtedâ ve haberden oluşan cümlenin fayda vermesi durumunda caiz olacağını, fayda vermemesi durumunda ise caiz olmayacağını ifade etmiştir (İbn Serrâc, I, 59).

ez-Zemahşerî (ö. 538/1144) ise, mübtedâ'nın ma ‘rife ve nekre olmak üzere iki çeşit olduğunu zikretmiştir. Nekre olan mübtedâ'nın da ya bir şeyle mevsuf olduğunu ya da istifham, nefi ve muhtas zarftan sonra geldiğini belirtmiştir (ez-Zemahşerî, 1993: 43).

İbn Yaîş (ö. 643/1245) de, bu konuda asıl olan mübtedâ'nın marife olmasıdır demiştir. Fakat mübtedâ'nın fayda vermesi nedeniyle bazı yerlerde nekre olarak geldiğini zikretmiştir. $\mathrm{O}$, mübtedâ'nın fayda vermesinin bu konuda esas olduğunu belirtmiştir (İbn Yaîş, 2001: I, 225).

İbnu'l-Hâcib (ö.646/1249 ise mübtedâ'nın ihtisas vecihlerinden biriyle mahsus olmas1 durumunda nekre olarak gelebileceğini ifade etmiştir (İbnu'l-Hâcib, 2010: 15).

İbn Mâlik (ö. 672/1274), nekre fayda vermediği müddetçe onunla ibtidâ etmenin caiz olmadığını belirtmiştir (İbn Mâlik, 17).

Müteahhirun olarak bilinen âlimler ise, nekreyle ibtidâ etmeyi caiz k1lan sebepleri ele alıp incelemiş ve onlar hakkında geniş bilgiler vermişlerdir (İbn Hişâm, 1985: 608). Fakat onlar da söz konusu sebeplerin sayısı hususunda ittifak etmemişlerdir. Nitekim onlardan bazıları, bu sebepleri umum ve husus ile bilinen bu iki ana sebebe hasrederken (İbn Hişâm, 9; İbn Kâsım el-Murâdî, 2008: I, 480), onlardan çoğu ise söz konusu sebepleri belli sayılarla ifade etmiş ve onları teker teker ele alıp incelemişlerdir. Nitekim İbn Mâlik, Şerhu'l-Kâfiyyeti 'ş-Şâfiyye' de bu sebeplerden altı (İbn Mâlik, I, 363-364), İbn Hişâm (ö. 761/1360), Muğnî'l-Lebîb'de on (İbn Hişâm, 1985: 608), Sabbân (ö. 1206/1792), Haşiyesinde on beş (Sabbân, 1997: I, 300), İbn 'Akil (ö. 769/1367), Şerhinde yirmi dört (İbn 'Akîl, 1980: I, 216-226), Ebû Hayyân (ö. 745/1344), İrtişâf (Ebû Hayyân, 1998: III, 100103) ve et-Tezyîl ve't-Tekmîl'de yirmi yedi (Ebû Hayyân, III, 325-333), es-Suyûtî (ö. 911/1505), elEşbâhu ve'n-Nezâir'de otuz bir tane sebep zikretmiştir (es-Suyûtî, II, 109). İbnü'n-Nehhâs (ö. 698/1299), et-Ta 'lik'de bu sebepleri otuz ikiye kadar sayarken (İbnu'n-Nehhâs, 2004: 149-152), el'Unnabî (ö. 776/1375) ise, et-Tezkire'de onları kırk ikiye çıkarmıştır (el-'Unnâbî, Sayı:12, 335).

\subsection{Mübtedâ'nın Nekre Olarak Geldiği Durumlar}

Mübtedâ belli durumlarda bazı sebeplerle nekre olarak gelebilir. Nahiv âlimleri, mübtedâ'nın nekre olarak gelmesini caiz kılan sebepler ve onların sayısı konusunda birbirinden farklı şeyler ifade etmişlerdir. Nahiv kaynaklarında geçen söz konusu sebeplere dikkat edildiğinde onlardan bir kısmı doğrudan nekre olan mübtedâyla, bir kısmı ondan önce geçen kelimelerle, bir kısmı da ondan sonra gelen sözcüklerle alakalı olduğu görülmektedir. Bu sebepler bütün kısımlarıyla aşağıda ayrı ayrı ele alınıp incelenecektir.

\section{Nekreden Önce geçen Sebepler}

Arap dilinde nekre olan isim, bazı isim ve harflerden sonra geldiğinde, bu isim ve harfler onu ma'rifeye yakınlaştırır ve faydalı olmasını sağlar. Dolayısıyla onlar kendilerinden sonra gelen

\section{Turkish Studies - Language and Literature}

Volume 14 Issue 4, 2019 
nekre ismin mübtedâ olarak gelmesini caiz kılmaya sebep olurlar. Nekre ismin bu sebeplerden sonra geldiği yerler ise nahiv kaynaklarında mübtedâ'nın nekre olarak gelmesinin caiz olduğu yerler olarak ifade edilmektedir. Nekrenin söz konusu sebeplerden sonra geldiği yerler şunlardır:

\subsection{Nekre, İstifham Edatından Sonra Geldiğinde}

Aralarında İbn Mâlik, İbn Hişâm, Ebû Hayyân ve Suyûtî’nin de bulunduğu birçok dilci, istifham edatlarından sonra gelen nekrenin fayda vermesi nedeniyle mübtedâ olabileceğini ifade etmişlerdir (İbn Mâlik, 17; İbn Hişâm, 1985: 612; Ebû Hayyân, III, 322; Suyûtî, I, 381; ezZemahşerî, 1993: 43; es-Sabbân, 1997: I, 300; İbn 'Akîl, 1980: I, 217; Suzan, 2001, 67). Örneğin,

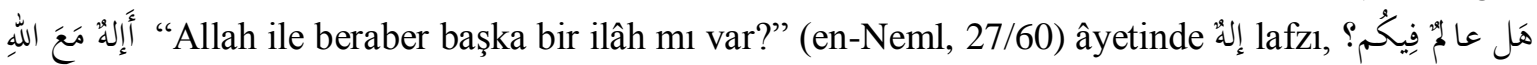
cümlesinde ise ع ع k kelimesi nekre isim oldukları halde istifham edatlarından sonra geldikleri için mübtedâ olmuşlardır.

\subsection{Nekre, Nefi Edatlarından SonraGeldiğinde}

Nefi edatlarından sonra gelen nekrenin mübtedâ olabileceğini ifade eden âlimler, bunun nedeni konusunda birbirinden farklı sebepler öne sürmüşlerdir. Nitekim, el-Vakkâd (ö. 905/), nefi edatlarından sonra gelen nekrenin umum bildirdiğinden (el-Vakkâd el-Ezherî, 2000: I, 209), İbn 'Amrûn (ö. 649/1251), ma'rifeye yakın olduğundan (es-Suyûtî, II, 124-125), İbn Yaîş, fayda verdiğinden (İbn Yaîş, 2001: I. 225), er-Radî (ö. 688/1289), muayyen olduğundan (er-Radî, 1996: I, 269), es-Sâğânî (ö. 650/1252) ise anlam yönünden fail anlamında olduğundan dolayı mübtedâ olarak gelmesi caiz olduğunu söylemişlerdir (Yâsir el-Harûb, 2010: V, Sayı, 1, 99-122).

Bu kısım için ما أَحَدُ خَيْرٌ مِنْكَكُ örneği verilebilir. Görüldüğü gibi bu cümlede nefi edatından sonra gelen iُ أَحُد kelimesi, yukarıda mezkur olan sebeplerden dolayı mübtedâ olmuştur.

\subsection{Nekre, لَول لَ'dan sonra Geldiğinde}

Nekreden önce geçip onun mübtedâ olarak gelmesini caiz kılan diğer bir sebepte لأ ؤ'dır. Nitekim birçok dilci, لَّ'dan sonra gelen nekrenin fayda vermesinden dolayı mübtedâ olabileceğini belirtmiş ve buna dair getirdikleri örnekler arasında şu şiiri zikretmişlerdir (es-Sabbân, 1997: I, 304; 1998: III, 100; Suyûtî, I, 383; İbn 'Akîl, 1980: I, 224). Görüldüğg̈ gibi bu şiirde لوَّ'dan sonra gelen ve nekre bir isim olan صطبار|kelimesi mübtedâ olmuştur.

\subsection{Nekre, إذِإِ el-Fücâiyyeden Sonra Geldiğinde}

Aralarında İbn Hişâm, Sabbân ve Suyûtî’nin de bulunduğu bazı âlimler, Iإِ el-fücâiyye'den sonra gelen nekrenin de mübtedâ olabileceğini ifade etmiş ve buna dair örnekler getirmişlerdir (İbn Hişâm, 1985: 613; es-Sabbân, 1997: I, 303; Suyûtî, I, 381; el-'Unnâbî, Sayı:12, 335). Onların

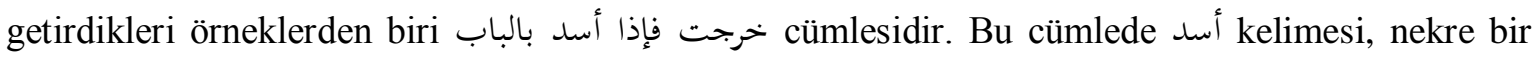
isim olmakla birlikte إذإٍ el-fücâiyye'den sonra geldiğinden dolayı mübtedâ olmuştur (İbn Hişâm, 1985: 613; es-Sabbân, 1997: I, 303; es-Suyûtî, I, 381). 


\subsection{Nekre, Vâv (واو)u'l-Hâliyyeden Sonra Geldiğinde}

Nekreden önce geçip onun mübtedâ olarak gelmesini caiz k1lan diğer bir sebepte vâvu'lhâliyyedir. Aralarında Ebû Hayyân, İbn Hişâm, Sabbân ve Suyûtî’nin yer aldığı birçok âlim, vâvu'l-hâliyyeden sonra gelen nekrenin de mübtedâ olabileceğini ifade etmiş ve buna dair örnek olarak da سَرَينا وبَنَمْ قَدْ أضاءَ şiiri zikretmişlerdir (Ebû Hayyân, 1998: III, 101; İbn Hişâm, 1985: 613; es-Sabbân, 1997: I, 303; es-Suyûtî, I, 383; İbn ‘Akîl, 1980: I, 225). Bu örnekte vâvu'l-hâliyyeden sonra gelip nekre bir isim olan kelimesi mübtedâ olmuştur.

\subsection{Nekre, Fâ (فاء)u'l-Cezâiyyeden Sonra Geldiğinde}

Dilcilerden birçok âlim, fâu'l-cezâiyye'den sonra gelen nekrenin fayda vermesi nedeniyle mübtedâ olabileceğini kaydetmiş ve buna dair إن ذَهَبَ عَيْرِ فَعَيْرِ في الرِّباطِ deyimi de örnek olarak vermişlerdir (Ebû Hayyân, 1998: III, 101; es-Sabbân, 1997: I, 303; es-Suyûtî, I, 383; İbn 'Akîl, 1980: I, 225; Nâziru'l-Ceyş, 1428: II, 926). Fakat Bedruddîn ed-Demâmînî (ö. 827/1424), bu deyimde geçip nekre bir isim olan عَيْر kelimesinin mübtedâ olmasını caiz kılan sebebin fâu'lcezâiyye değil, ondan sonra mukadder olan آخرvasfı olduğunu zikretmiştir (ed-Demâmînî, 1983: III, 55).

\subsection{Nekre, Lâm (لام)'ı İbtidâyye'den Sonra Geldiğinde}

Lâm-1 ibtidâyye'den sonra gelen nekrenin de mübtedâ olabileceği hususu bazı dilci tarafindan ifade edilmiştir (İbnu'n-Nehhâs, 2004: 151; es-Sabbân, 1997: I, 303; İbn 'Akîl, 1980: I,

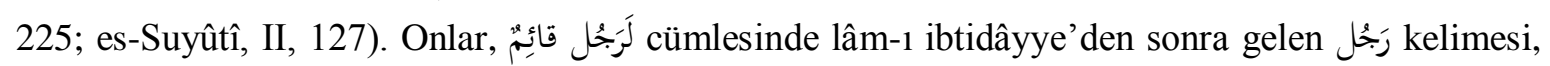
nekre isim olmakla birlikte fayda vermesi nedeniyle mübtedâ olarak geldiğini söylemişlerdir (esSabbân, 1997: I, 303; İbn 'Akîl, 1980: I, 225; es-Suyûtî, II, 127).

\subsection{Nekre, Hasr Edatından Sonra Geldiğinde}

Bazı âlimler, hasr edatından sonra gelen nekrenin de mübtedâ olabileceğini belirtmişlerdir

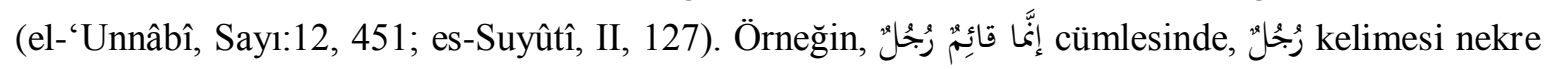
bir isim olduğu halde hasr edatından sonra geldiği için mübtedâ olmuştur.

\subsection{Nekre, Nefye Cevap Olup إِّ 'den Sonra Geldiğinde}

Bazı âlimler, nefye cevap olup إِ olduğunu söylemişlerdir (İbnu'n-Nehhâs, 2004: 152; el-'Unnâbî, Sayı:12, 453; es-Suyûtî, II, 128).

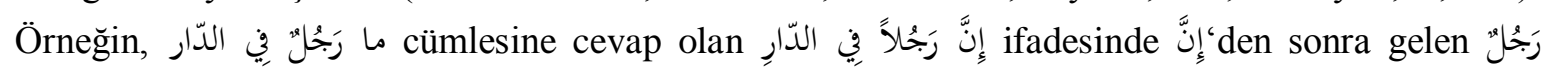
kelimesi, nekre bir isim olmakla birlikte mübtedâ olmuştur.

\subsection{Nekre, Zarf Olan Haberinden Sonra Geldiğinde}

Aralarında ez-Zemahşerî, Ebû Hayyân ve Ebû Mûsâ el-Cezûlî (ö. 607/1210)'nin de bulunduğu birçok dilci, haberi mukaddem bir zarf olan nekrenin de mübtedâ olabileceğini zikretmişlerdir (ez-Zemahşerî, 1993: 43; Ebû Hayyân, 1998: III, 101;el-Cezûlî, 93; İbnu'n-Nehhâs, 2004: 150; es-Suyûtî, II, 125; el-'Unnâbî, Say1:12, 453; İbn Hişâm, 1985: 611; İbn Mâlik, I, 


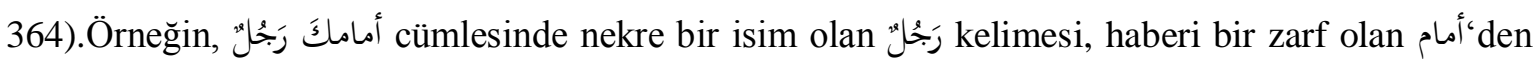
sonra gelip mübtedâ olmuştur.

\subsection{Nekre, Câr ve Mecrûr Olan Haberinden Sonra Geldiğinde}

Aralarında Zemahşerî, Ebû Hayyân ve İbn Hişâm'ın da bulunduğu birçok dilci, haberi mukaddem bir câr ve mecrûr olan nekrenin de mübtedâ olabileceğini ifade etmişlerdir (ezZemahşerî, 1993: 43; Ebû Hayyân, 1998: III, 101; İbnu'n-Nehhâs, 2004: 150; es-Suyûtî, II, 125; el'Unnâbî, Say1:12, 453; İbn Hişâm, 1985: 613; İbn Mâlik, I, 364). Örneğin, فِي الدّارِ رَجُجلْ cümlesinde nekre bir isim olan رَجُعُ kelimesi, mukaddem bir câr ve mecrûrdan oluşan haberinden sonra gelip mübtedâ olmuştur.

\subsection{Nekre, Cümle Olan Haberinden Sonra Geldiğinde}

Bazı âlimler, haberi mukaddem bir cümle olan nekrenin de mübtedâ olabileceğini ifade emişlerdir (Ebû Hayyân, III, 303; İbnu'n-Nehhâs, 2004: 151; es-Suyûtî, II, 128; el-'Unnâbî,

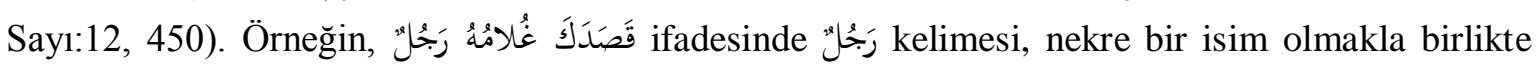
cümle olarak gelen haberinden sonra gelip mübtedâ olmuştur.

\subsection{Nekre, Kendi Haberinin Ma'mûlünden Sonra Geldiğinde}

Bazı dilciler, kendi haberinin ma'mûlünden sonra gelen nekrenin de mübtedâ olabileceğini belirtmişlerdir (el-'Unnâbî, Sayı:12, 453; es-Suyûtî, II, 131). Örneğin, "إنَّ فِ دَراِهمكَ أَلْفاً بِيضُ ifadesinde geçen ve nekre bir isim olan أَلْفاً kelimesi, إنَّ harfi onu naspetmeden önce kendi haberinin ma'mûlünden sonra gelip mübtedâ olmuştur.

\subsection{Nekre, Nekre Bir Mübtedâya Ma'tûf Olduğunda}

Aralarında İbn Mâlik, İbn Hişâm ve Suyûtî’nin de bulunduğu birçok âlim, nekre bir mübtedâya ma'tûf olan nekrenin de mübtedâ olabileceğini zikretmiş ve şu şiiri de: عُنِي إصْطِبارُ وشَكْوَى ona örnek olarak vermişlerdir (İbn Mâlik, I, 364; İbn Hişâm, 1985: 609-610 es-Suyûtî, II, 130, I, 382; İbnu'n-Nehhâs, 2004: 152; el-'Unnâbî, Say1:12, 444; es-Sabbân, 1997: I, 301-302; İbn 'Akîl, 1980: I, 222; el-Cebbûrî, 2010: 460). Ancak Ebû Hayyân, bu şiirin söz konusu atfa mahsus bir örnek olamayacağını belirtmiştir. O, bu şiirde nekre bir isim olan olan عِنِِّ zarfindan dolayı da mübtedâ olmuş ihtimali olduğunu ifade etmiştir (Ebû Hayyân, III, $328)$.

\subsection{Nekre, Ma'rife Bir Mübtedâ'ya Ma'tûf Olduğunda}

Aralarında Ebû Hayyân, İbn Hişâm ve İbn 'Akîl'in de bulunduğu birçok dilci, ma'rife birmübtedâ'ya ma'tûf olan nekrenin de mübtedâ olabileceğini ifade etmişlerdir (Ebû Hayyân, 1998: III, 100; İbn Hişâm, 1985: 609-610; İbn 'Akîl, 1980: I, 222; el-'Unnâbî, Sayı:12, 444; es-Sabbân,

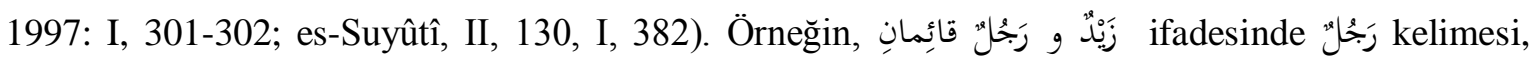
nekre bir isim olmakla beraber ma'rife bir mübtedâ olan زَيْد sözcüğüne ma'tûf olduğundan dolay1 mübtedâ olması caiz görülmüştür. 


\subsection{Nekre, Soruya Cevap Olarak Geldiğinde}

Bazı âlimler, soruya cevap olarak gelen nekrenin de mübtedâ olabileceğini ifade etmişlerdir (Ebû Hayyân, III, 330; es-Sabbân, 1997: I, 304; es-Suyûtî, II, 131, I, 382; el-'Unnâbî, Sayı:12,

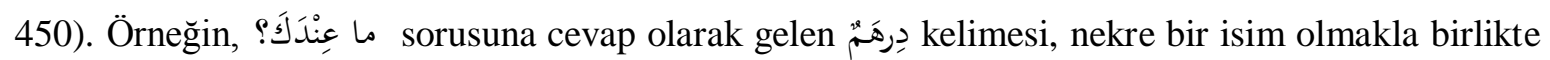
درِهَمْ عِنْدِي takdirinde olup mübtedâ olmuştur.

\subsection{Nekre, Hemze (أ) ve em (أَمْ) ile Sorulan Soruya Cevap Olduğunda}

Birçok dilci, hemze ve í ile sorulan soruya cevap olarak gelen nekrenin de mübtedâ olarak gelmesi caiz olduğunu söylemişlerdir (İbnu'l-Hâcib, 2010: 16; er-Radî, 1996: I, 260; İbnu'n-

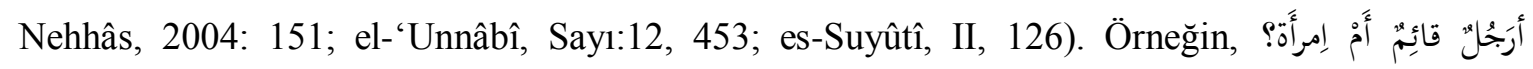

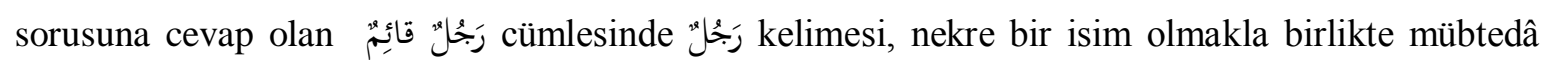
olmuştur.

\subsection{Nekre, İtiraz Amacıyla Kullanıldığında}

el-'Unnâbî, itiraz etmek amaciyla getirilen nekrenin de mübtedâ olabileceğini ifade etmiştir

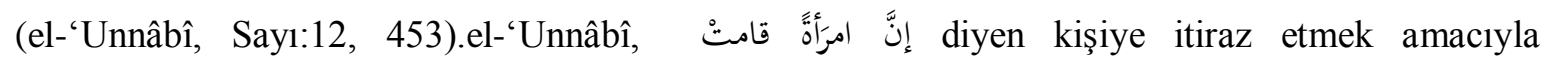

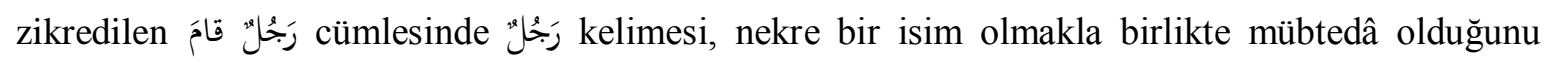
söylemiştir (el-'Unnâbî, Sayı:12, 453).

\section{Nekreden Sonra Gelen Sebepler}

Nekre isimden sonra gelen bazı isim ve harfler, nekreyi ma'rifeye yakınlaştırır ve faydalı olmasını sağlar. Bu nedenle söz konusu isim ve harfler, kendilerinden önce geçen nekrenin mübtedâ olarak gelmesinin caiz olmasına sebep olurlar. Bu nekrenin söz konusu isim ve harflerden sonra mübtedâ olarak geldiği yerler şunlardır:

\subsection{Nekre, Açık Bir Sıfatla Mevsuf Olduğunda}

Sîbeveyhi başta olmak üzere hemen hemen bütün dilciler, açı bir sıfatla mevsuf olan nekrenin mübtedâ olabileceğini zikretmişlerdir (Sîbeveyhi, 1988: I, 329; İbn Serrâc, I, 59; ezZemahşerî, 1993: 43; İbn Mâlik, I, 364; Ebû Hayyân, 1998: III, 100;es-Suyûtî, II, 110, I, 381; er-

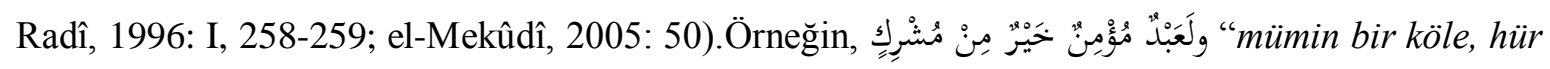
bir müşrikten daha iyidir" (el-Bakara, 2/221) âyetinde عَبْْ kelimesi, nekre bir isim olduğu halde مُؤَوْمنْ sözcügüyle mevsuf olduğundan dolay1 mübtedâ olmuştur. Dilcilerin çoğu, sıfat nekreyi marifeye yakınlaştıran bir etken ve onu faydalı bir isim haline getiren bir sebep olduğunu belirtmiş ve bu nedenle herhangi bir sıfatla mevsuf olan nekrenin mübtedâ olabileceğini zikretmişlerdir (İbn Serrâc, I, 59; İbn Mâlik, I, 363; Ebû Hayyân, 1998: III, 100;es-Suyûtî, II, 110, I, 381; er-Radî, 1996: I, 258-259; el-Mekûdî, 2005: 50).Fakat İbn Hişâm, söz konusu nekrenin mübtedâ olabilmesi için fayda veren bir sıfatla mevsuf olması gerektiğini söylemiştir (İbn Hişâm, 1985: 608-609). İbn Hâcib ise nekrenin sıfatla mevsuf olması nedeniyle mübtedâ olamayacağını zikretmiş ve yukarıda geçen âyette ise umum bildiren كُّلُ kelimesinin mukadder olduğunu beyan etmiştir. $O$, bu âyetin

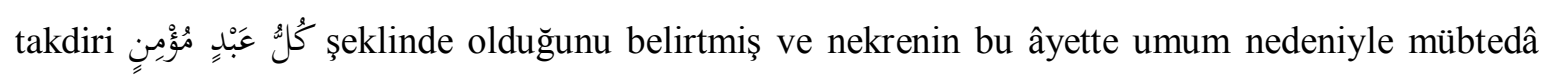
olduğunu ifade etmiştir (İbnu'l-Hâcib, I, 184-185).

\section{Turkish Studies - Language and Literature}

Volume 14 Issue 4, 2019 


\subsection{Nekre, Mukadder Bir Sıfatla Mevsuf Olduğunda}

Dilciler, açık olan sıfatta olduğu gibi mukadder bir sıfatla mevsuf olan nekre ismin de mübtedâ olabileceğini belirtmişlerdir (Ebû Hayyân, III, 325, 1998: III, 100; ed-Demâmînî, 1983: III, 49; es-Suyûtî, II, 110, I, 381; Nâziru'l-Ceyş, 1428: II, 922; İbn Hişâm, 1985: 609). Örneğin, cümlesinde السِّمْنُ مَنوانِ بِدِرْهَمِ مِن ifadesiyle mevsuf olduğundan dolayı mübtedâ olmuştur. İbnu'n-Nehhas ile el-‘Unnâbî, nekrenin mübtedâ olmasını caiz kılan sebepleri ele incelerken, açık sıfatla mevsuf olan nekreyi ayrı bir kısım, mukadder sıfatla mevsuf olan nekreyi de ayrı bir kısım olarak saymışlardır (İbnu'n-Nehhâs, 2004: 149; el-'Unnâbî, Sayı:12, 442). Ancak bu her iki sıfat çeşidini bir sebep olarak görmek daha isabetli olduğunu düşünüyorum. Zira ister sıfat açık olsun ister mukadder olsun sebep aynıdır. Söz konusu sebepte herhangi bir değişim yoktur.

\subsection{Nekre, Mevsufun Yerine Geçtiğinde}

Bazı dilciler, mevsufun yerine geçen nekrenin de mübtedâ olabileceğini zikretmiş ve buna örnek olarak da ضَعَيفُ عاذَ بِعَرْمَلَة cümlesini getirmişlerdir (Ebû Hayyân, III, 325, 1998: III, 101; esSuyûtî, I, 381; Nâziru'l-Ceyş, 1428: II, 922; İbn Hişâm, 1985: 609). Onlara göre bu cümlede kelimesi, mahzuf mevsufu olan إنسانُ sözcüğünün yerine geçtiği için mübtedâ olmuştur. Fakat Ebû Hayyân ile ed-Demâmînî'nin de aralarında bulunduğu bazı âlimler, bu cümlede nekre bir isim olan ضَعِيف kelimesi, vasıf olduğundan dolayı mübtedâ olduğunu söylemişlerdir (Ebû Hayyân, III, 325; ed-Demâmînî, 1983: III, 48; Nâziru'l-Ceyş, 1428: II, 922; es-Suyûtî, I, 381).

\subsection{Nekre, Manevî Bir İzafetle Muzaf Olduğunda}

Bazı dilciler, manevî bir izafetle muzaf olan nekrenin de mübtedâ olabileceğini zikretmişlerdir (İbnu'n-Nehhâs, 2004: 151; el-'Unnâbî, Sayı:12, 444; İbn 'Akîl, 1980: I, 228).

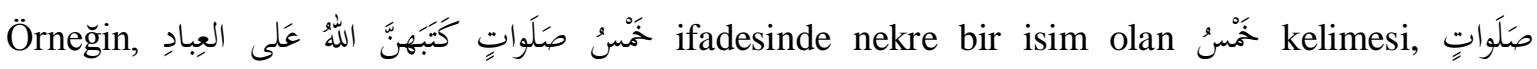
sözcügüne manevî bir izafetle muzaf olduğundan dolayı mübtedâ olmuştur. Ancak aralarında İbn Mâlik, Ebû Hayyân, İbn Hişâm ve Suyûtî’nin de bulunduğu birçok âlim, muzaf olan nekreyi ayrı bir kısım olarak saymamış, onu bu sebeplerden biri olan amel eden nekreden addetmişlerdir (İbn Mâlik, I, 363; Ebû Hayyân, III, 326, 1998: III, 100; İbn Hişâm, 1985: 610; es-Sabbân, 1997: I, 301; es-Suyûtî, I, 382; Nâziru'l-Ceyş, 1428: II, 923).

\subsection{Nekre, Lafzî Bir İzafetle Muzaf Olduğunda}

Bazı dilciler, lafzî bir izafetle muzaf olan nekrenin de mübtedâ olabileceğini zikretmiş ve مِنُُْكَكَ لا يَفْعَلُ كَذا cümlesini de buna örnek olarak vermişlerdir (İbnu'n-Nehhâs, 2004: 151; el'Unnâbî, Say1:12, 444). Onlara göre, bu cümlede nekre bir isim olan مِ مelimesi, kendisine bitişen zamire lafzî bir izafetle muzaf olması sebebiyle mübtedâ olmuştur. Fakat aralarında İbn Hişâm, Sabbân ve Suyûtî’nin de bulunduğu birçok âlime göre, bu cümlede nekre bir isim olan مِنْ kelimesi, kendisine bitişen muttasıl zamire muzaf olduğu için değil, onda amel ettiğinden dolayı mübtedâ olmuştur (İbn Hişâm, 1985: 610; es-Sabbân, 1997: I, 301; es-Suyûtî, I, 382; ed-Demâmînî, 1983: III, 50).

\subsection{Nekreye, Mübtedâ Olması Caiz Olan Bir Nekre Matuf Olduğunda}

Dilcilerden birçok âlim, mübtedâ olarak gelmesi caiz olan bir nekrenin, matuf olduğu nekrenin de mübtedâ olabileceğini belirtmişlerdir (Ebû Hayyân, III, 326, 1998: III, 100; İbn Hişâm, 
1985: 610; İbnu'n-Nehhâs, 2004: 152; el-“Unnâbî, Say1:12, 445; es-Sabbân, 1997: I, 301-302; es-

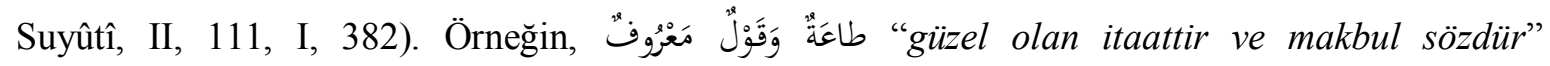

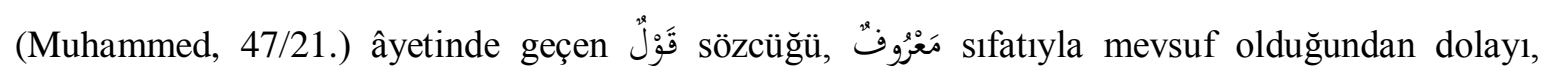
mübtedâ olması caiz görülmüştür. Bu kelimenin, طَعَ sözcügüne olan atfı da nekre bir isim olan طاعَة sözcüğünün mübtedâ olmasını caiz kılan sebep olmuştur.

\subsection{Nekrenin Haberi Mukayyet Olduğunda}

el-'Unnâbî, haberi mukayyet olan nekrenin de mübtedâ olabileceğini zikretmiştir (el'Unnâbî, Say1:12, 453). Ona göre, إنسانُ cümlesindelimesi, nekre bir

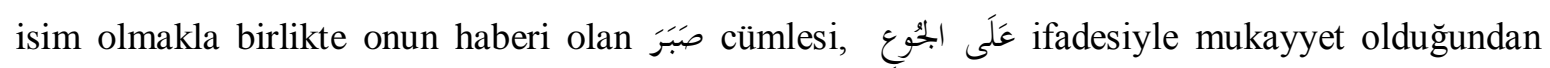
dolayı mübtedâ olması caiz olmuştur (el-'Unnâbî, Sayı:12, 453).

\section{Doğrudan Nekreden Kaynaklanan Sebepler}

Arap dilinde, bazı nekreler umum veya husus bildirmekte veyahut ma'rife kelimelerde bulunan bazı özelliklere sahip olmaktadırlar. Bu özelliklere haiz olan nekreler, muhataba fayda verdikleri için mübtedâ olarak gelebilmektedirler. Bu özellikleri taşıyan nekreler, nahiv kaynaklarında nekrenin mübtedâ olarak gelmesi caiz olduğu yerler olarak ifade edilmektedir. $\mathrm{Bu}$ yerler ise şunlardır:

\subsection{Nekrenin Tafsil Amacıyla Gelmiş Olması}

Birçok dilci, kelamı tafsil etmek ve detaylandırmak amacıyla gelen nekrenin mübtedâ olabileceğini zikretmiştir (Ebû Hayyân, III, 327, 1998: III, 100; İbn Hişâm, 1985: 613; İbnu'nNehhâs, 2004: 151; el-'Unnâbî, Sayı:12, 446; es-Suyûtî, I, 382; İbn 'Akîl, 1980: I, 219; Nâziru'l-

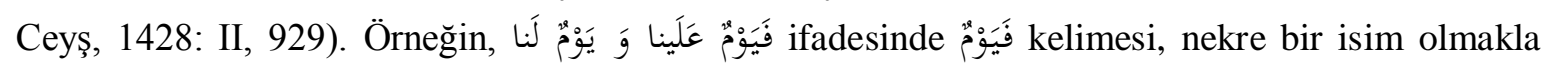
birlikte, daha önce geçen kelamı tafsil etmek ve detaylandırmak amacıyla geldiği için mübtedâ olmuştur.

\subsection{Nekrenin el Takısını Kabul Etmemesi Sebebiyle Ma'rifeye Yakınlaşmış Olması}

Bazı âlimler, el-takısını kabul etmeyen nekrenin ma'rifeye yakınlaştı̆̆ını belirtmiş ve bu nedenle onun da mübtedâ olabileceğini zikretmişlerdir (İbnu'n-Nehhâs, 2004:149; el-'Unnâbî,

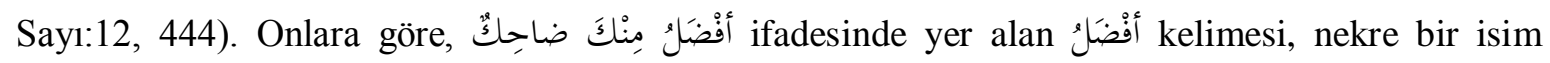
olmakla birlikte el-takısını kabul etmediğinden dolayı ma'rifeye yakınlaşmış ve bu nedenle mübtedâ olması caiz görülmüştür (İbnu'n-Nehhâs, 2004:149; el-'Unnâbî, Sayı:12, 444). Fakat Ebû Hayyân, burada مِنْ harfi, أفضِلْ kelimesine taalluk ettiği için bunun müstakil bir sebep olmadığını ifade etmiş ve bunun, amel etmesi nedeniyle mübtedâ olması caiz olan nekreye dahil olduğunu söylemiştir (Ebû Hayyân, III, 332).

\subsection{Nekrenin Umum Bildirmesi}

Dilciler, umum bildiren nekrenin de mübtedâ olabileceğini kaydetmişlerdir (Ebû Hayyân, III, 328, 1998: III, 100; İbn Hişâm, 1985: 611; İbnu'n-Nehhâs, 2004: 150; el-'Unnâbî, Say1:12, 447; es-Sabbân, 1997: I, 300-302; es-Suyûtî, II, 111, I, 382; İbn 'Akîl, 1980: I, 219). Örneğin, كُّ

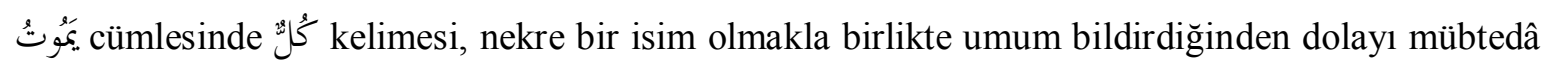
olmuştur. 


\subsection{Nekreden Belli Bir Şahıs Murat Edildiğinde}

Bazı âlimler, kendisinden belli bir şahsın kastedildiği nekrenin de mübtedâ olabileceğini belirtmişlerdir (İbnu'n-Nehhâs, 2004: 151; el-'Unnâbî, Sayı:12, 454; Nâziru'l-Ceyş, 1428: II, 930).

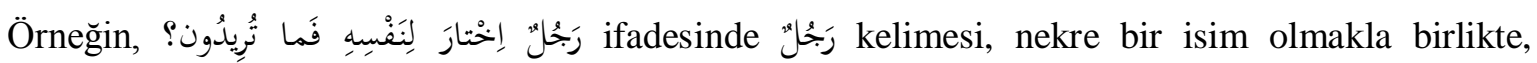
kendisinden belli bir şahıs kastedildiğinden dolayı mübtedâ olmuştur.

\subsection{Nekreden Belli Bir Şahıs Murat Edilmediğinde}

Bazı dilciler, kendisinden belli bir şahıs murat edilmeyen nekrenin de mübtedâ olabileceğini ifade etmişlerdir (Ebû Hayyân, III, 334, 1998: III, 102;el-'Unnâbî, Say1:12, 454; es-

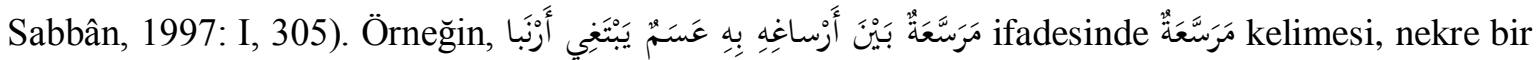
isim olmakla birlikte, kendisinden belli bir şahıs murat edilmediğinden dolayı mübtedâ olmuştur.

\subsection{Nekre, İstifham İsmi Olduğunda}

Dilciler, istifham ismi olan nekrenin de mübtedâ olabileceğini zikretmişlerdir (Ebû Hayyân, III, 330, 1998: III, 101; İbn Hişâm, 1985: 611; İbnu'n-Nehhâs, 2004: 149; el-'Unnâbî, Say1:12, 450; es-Sabbân, 1997: I, 300; es-Suyûtî, II, 111, I, 382). Örneğin, مَنْ kelimesi, nekre bir isim olmakla birlikte istifham ismi olduğundan dolayı mübtedâ olarak gelmiştir.

\subsection{Nekre, Şart Bildiren Bir İsim Olduğunda}

Âlimler, şart bildiren nekre ismin de mübtedâ olabileceğini belirtmişlerdir (Ebû Hayyân, III, 332, 1998: III, 101; İbn Hişâm, 1985: 611; İbnu'n-Nehhâs, 2004: 149; el-'Unnâbî, Say1:12, 450; es-Sabbân, 1997: I, 300; es-Suyûtî, II, 111, I, 382; İbn 'Akîl, 1980: I, 219). Örneğin, مَنْ يَقْم مَنْ kelimesi, nekre bir isim olmakla birlikte şart bildiren bir isim olduğu için mübtedâ olarak gelmesi caiz olmuştur.

\subsection{Nekre, Haber Bildiren كَ Olduğunda}

Bazı dilciler, nekre haber bildiren ¡ं olduğunda onun mübtedâ olarak gelmesi caiz olduğunu söylemişlerdir (Ebû Hayyân, III, 332, 1998: III, 101; İbn Hişâm, 1985: 611; İbnu'n-

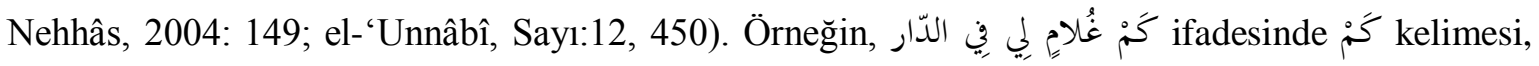
nekre bir isim olmakla birlikte haber bildiren ${ }^{\circ}$ olduğundan dolayı mübtedâ olarak gelmiştir.

\subsection{Nekre, Taaccüp Bildiren L Olduğunda}

Sîbeveyhi'nin de aralarında birçok dilci, nekre isimlerinden olan taaccüp Lo'sının da mübtedâ olabileceğini ifade etmişlerdir (Sîbeveyhi, 1988: I, 37; Ebû Hayyân, III, 328;İbnu'nNehhâs, 2004: 151; el-'Unnâbî, Sayı:12, 447; Nâziru'l-Ceyş, 1428: II, 925; er-Radî, 1996: I, 259;

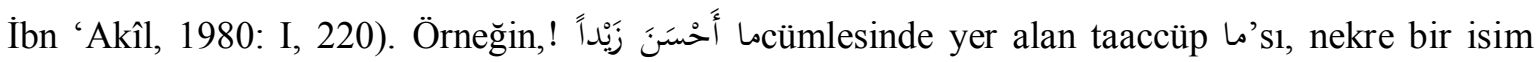
olmakla birlikte mübtedâ olmuştur.

\section{10. Nekre, 'Amel Eden Bir İsim Olduğunda}

Dilciler, 'amel eden nekrenin de mübtedâ olabileceğini zikretmişlerdir (İbn Mâlik, I, 363; Ebû Hayyân, III, 326, 1998: III, 100; İbnu'n-Nehhâs, 2004: 151; el-'Unnâbî, Sayı:12, 444; İbn Hişâm, 1985: 609; es-Sabbân, 1997: I, 301; er-Radî, 1996: I, 258- 259; es-Suyûtî, I, 382; Nâziru'l- 


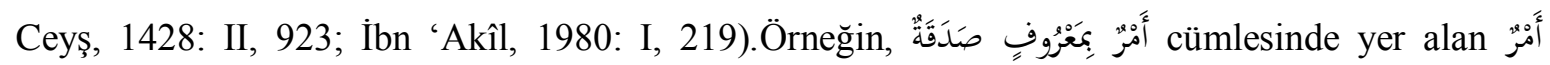
kelimesi, nekre bir isim olmakla birlikte kendisinden sonra gelen kısımda 'amel ettiği için mübtedâ olmuştur.

\subsection{Nekre, Taaccüp Bildiren Bir Kelime Olduğunda}

Âlimler, nekre taaccüp bildiren bir kelime olduğunda da mübtedâ olabileceğini belirtmişlerdir (Ebû Hayyân, 1998: III, 100; İbnu'n-Nehhâs, 2004: 149; el-'Unnâbî, Sayı:12, 447; İbn Hişâm, 1985: 612; es-Suyûtî, II, s. 112, I, 382; Nâziru'l-Ceyş, 1428: II, 929; İbn 'Akîl, 1980: I,

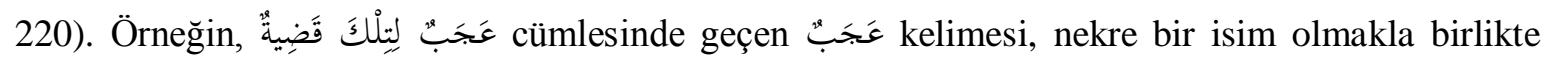
taaccüp bildiren bir isim olduğu için mübtedâ olması caiz olmuştur.

\subsection{Nekre, Dua Bildiren Bir Kelime Olduğunda}

Birçok dilci, nekre dua bildiren bir kelime olması durumunda mübtedâ olabileceğini ifade etmişlerdir (Ebû Hayyân, III, 330, 1998: III, 101; İbnu'n-Nehhâs, 2004: 150; el-‘Unnâbî, Say1:12,

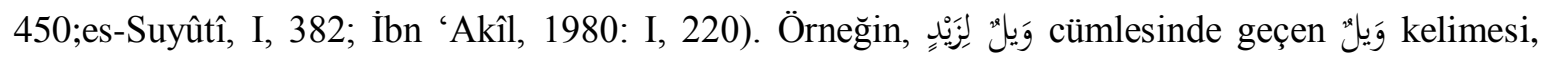
nekre bir isim olduğu halde dua bildiren bir isim olduğu için mübtedâ olması caiz olmuştur. Bazı âlimler, bu sebebi fiil manasında olan nekre çeşidi altında ele almışlardır (İbn Hişâm, 1985: 612; es-Sabbân, 1997: I, 302; es-Suyûtî, II, 112).

\subsection{Nekre, Tasgir İsmi Olduğunda}

Birçok âlim, tasgir ismi olan nekrenin de mübtedâ olabileceğini zikretmişlerdir (Ebû Hayyân, III, 332, 1998: III, 101; İbnu'n-Nehhâs, 2004: 151; el-‘Unnâbî, Sayı:12, 450; es-Suyûtî, I,

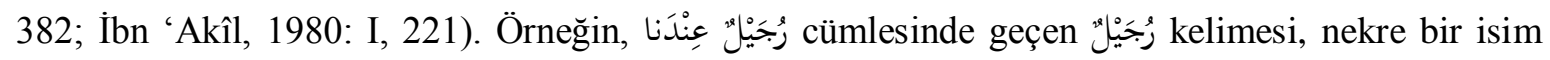
olmakla birlikte tasgir ismi olduğu için mübtedâ olarak gelmesi caiz olmuştur. Bazı âlimler, tasgir ismi manen mevsuf olan nekre ismin altında ele alıp incelemişlerdir (İbn Hişâm, 1985: 609; esSabbân, 1997: I, 301; es-Suyûtî, II, 110).

\subsection{Nekre, Beklenmedik Bir Anlam Bildirdiğinde}

el-'Unnâbî, beklenmedik bir anlamı bildirmek amacıyla gelen nekrenin de mübtedâ olabileceğini zikretmiştir (el-'Unnâbî, Say1:12, 452).el-'Unnâbî, ! شَيء ما جاءَ بِكَ 'ifadesinde yer alan شَيء kelimesinin, nekre bir isim olmakla birlikte beklenmedik bir anlamı bildirdiğinden dolayı mübtedâ olarak geldiğini belirtmiştir (el-'Unnâbî, Sayı:12, 452).

\subsection{Nekre, Emir Bildiren Bir Kelime Olduğunda}

el-'Unnâbî, emir bildiren nekrenin de mübtedâ olabileceğini ifade etmiştir (el-'Unnâbî, Say1:12, 453). el-“Unnâbî, وَصِيُّ لأزواجِجِم "kendi eşleri için vasiyet etsinler" (el-Bakara, 2/240.) âyetinde geçen وَصِيُّة kelimesi, nekre bir isim olmakla birlikte emir bildiren birisim olduğundan dolayı mübtedâ olduğunu zikretmiştir (el-‘Unnâbî, Sayı:12, 453).

\subsection{Nekre, Fiil Anlamında Olan Bir Kelime Olduğunda}

Bazı âlimler, fiil anlamında olup nefi ve istifham edatlarından sonra gelmeyen nekrenin de mübtedâ olabileceğini kaydetmişlerdir (Ebû Hayyân, III, 333, 1998: III, 102; İbnu'n-Nehhâs, 2004: 151; el-‘Unnâbî, Sayı:12, 450). Onlar, قائمان الزَّيدان ifadesinde geçen قائمان kelimesi, nekre bir isim 
olmakla birlikte fiil anlamında olan bir isim olduğundan dolayı mübtedâ olduğunu söylemişlerdir (Ebû Hayyân, III, 333, 1998: III, 102; İbnu'n-Nehhâs, 2004: 152; el-'Unnâbî, Sayı:12, 454).

\subsection{Nekreyle Başlayan Cümlenin Başka Bir Cümle Anlamında Olduğunda}

Bazı âlimler, nekreyle başlayan cümlenin başka bir cümle anlamında olması durumunda cümlenin başında yer alan nekrenin de mübtedâ olabileceğini zikretmişlerdir (İbnu'n-Nehhâs,

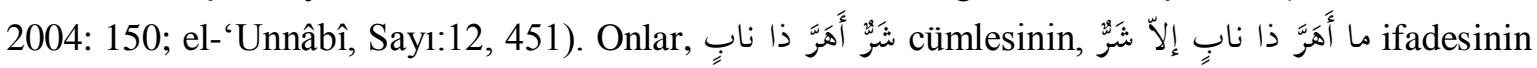

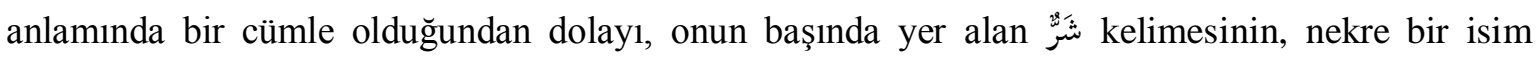
olmakla birlikte mübtedâ olarak geldiğini söylemişlerdir. Fakat bazı âlimlere göre, bu örnekte kelimesi, mukadder olan عَظِيم sifatiyla mevsuf olduğundan dolayı mübtedâ olarak gelmesi caiz olmuştur (İbn Hişâm, 1985: 609; es-Sabbân, 1997: I, 301; es-Suyûtî, I, 382).

\subsection{Nekrenin Haberi, Olağan Üstü Bir Anlam İfade Ettiğinde}

Dilciler, haberi olağan üstü bir anlam ifade eden nekrenin de mübtedâ olabileceğini kaydetmişlerdir (Ebû Hayyân, III, 325; İbn Hişâm, 1985: 613; es-Sabbân, 1997: I, 303; es-Suyûtî,

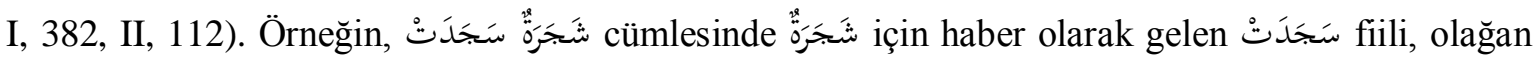

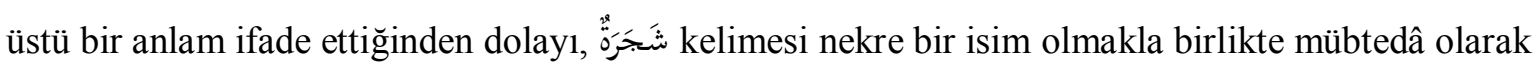
gelmiştir.

\section{Kur'ân'da Mübtedâ'nın Nekre Olarak Geldiği Bazı Örnekler}

Kur'ân'1 Kerîm'in birçok yerinde muhtelif sebeplerle mübtedâ'nın nekre olarak geldiği görülmektedir. Kur'ân'da mübtedânın nekre olarak geçtiği örnekler iyi bir şekilde incelendiğinde onun şu gramatik sebeplerle nekre olarak geldiği anlaşılmaktadır:

\subsection{Nekre, Bir Sıfatla Mevsuf Olduğunda}

Sıfatla mevsuf olması nedeniyle nekre olarak gelen mübtedânın örnekleri Kur'ân'1 Kerîm' in muhtelif yerlerinde geçmektedir. Konun uzatılmaması amaciyla bunlardan sadece bir

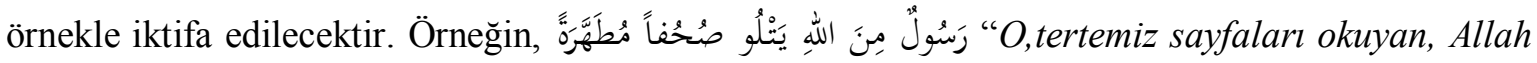

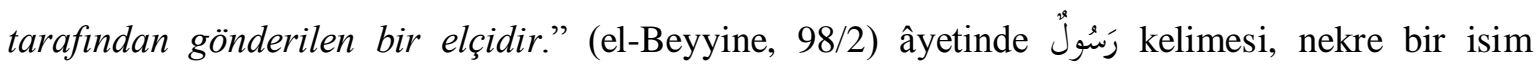
olmakla birlikte mübtedâ olmuştur. Onun mübtedâ olmasını caiz kılan sebep ise ona sıfat olarak gelen مِنَ اللهِ ifadesidir.

\subsection{Nekre, Amil Olduğunda}

Fiil gibi amel eden nekre de mübtedâ olarak gelebilir. Kur'ân'1 Kerîm'de buna dair çok sayıda örnek bulunmaktadır. Bu örneklerden biri أَداءٌ إلَيهِ بإِحسانٍ 'Ona güzellikle diyet ödemek gerekir..." (el-Bakara, 2/178) âyetidir. Nitekim bu âyette أَداءُ kelimesi, nekre bir isim olmakla birlikte kendisinden sonra gelen إلَِّيه ifadesinde amel eden bir isim olduğu için mübtedâ olmuştur.

\subsection{Nekre, Dua Anlamında Bir Kelime Olduğunda}

Dua anlamında olan nekrenin de mübtedâ olarak gelmesi caizdir. Kur'ân'da buna dair

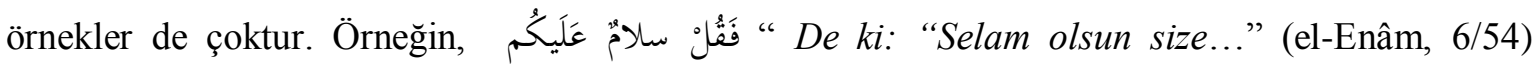




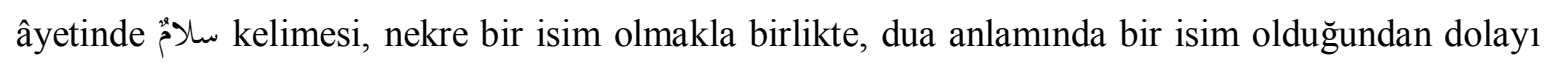
mübtedâ olmuştur.

\subsection{Nekre, Umum Bildiren Bir Kelime Olduğunda}

Umum bildiren nekre de mübtedâ olabilir. Kur'ân'da bunun da örnekleri çoktur. Örneğin,

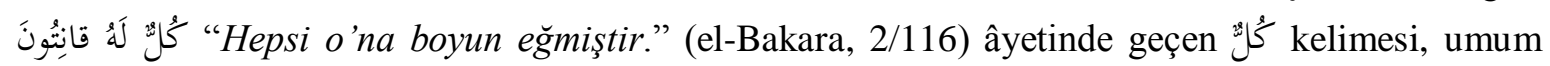
bildiren bir mübtedâdır. Bu kelime nekre bir isim olmakla birlikte umuma delalet eden bir sözcük olması, onun mübtedâ olarak gelmesini caiz kılmıştır.

\subsection{Nekre, Tafsil Amacıyla Gelen Bir Kelime Olduğunda}

Kendisinden önce geçenleri tafsil etmek amaciyla gelen nekrenin de mübtedâ olması caizdir. Kur'ân'da buna dair çok sayıda örnek bulunmaktadır.

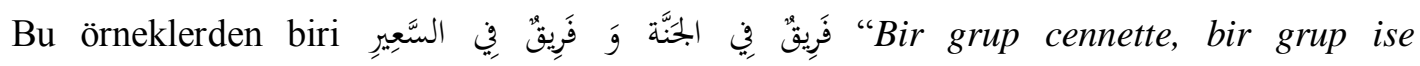

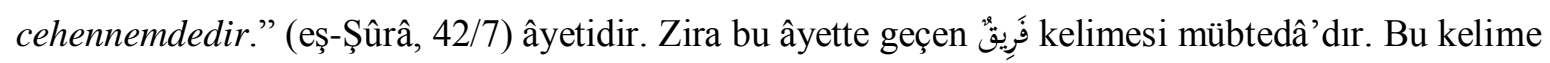
nekre bir sözcük olduğu halde tafsil amaciyla gelen bir isim olduğu için mübtedâ olarak gelmiştir.

\subsection{Nekre, Mukadder Bir Soruya Cevap Olduğunda}

Mukadder bir soruya cevap olan nekrenin de mübtedâ olarak gelmesi caizdir. Kur'ân'da buna dair şu örnek verilebilir: سُورةٌ أَنَزْلْناهـ “Bu bizim indirdiğimiz bir sûredir.” (en-Nûr, 24/1)

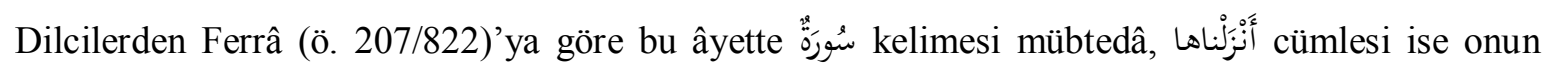
haberidir. Nekre bir isim olan bu kelimenin mukadder bir soruya cevap olması, onun mübtedâ olarak gelmesini caiz kılmıştır.

\subsection{Nekreye, Bir Mübtedâ Matuf Olduğunda}

Bir mübtedâ'nın kendisine matuf olduğu nekrenin de mübtedâ olması caizdir. Kur'ân'da bu kısma dair örnekler de mevcuttur. Örneğin, طَاعَة وَ قَولْ مَعْرُوفْ "Güzel olan itaattir ve makbul

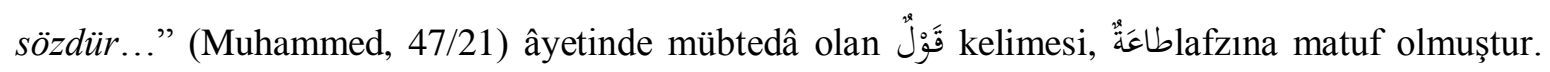
Onun bu atfı, nekre bir isim olan طُعَُّ kelimesinin de mübtedâ olmasını caiz kılmıştır.

\subsection{Nekre, Bir Mübtedâ'ya Matuf Olduğunda}

Bir mübtedâ'ya matuf olan nekrenin de mübtedâ olarak gelmesi caizdir. Kur'ân'da buna

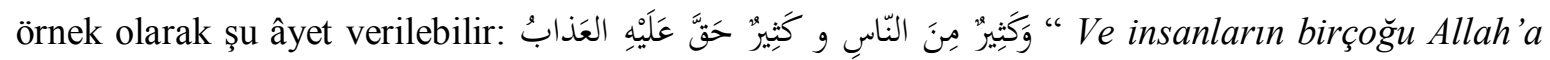
secde etmektedirler. Birçoğunun üzerine de azap hak olmuştur...” (el-Hac, 22/8) Nitekim bu âyette

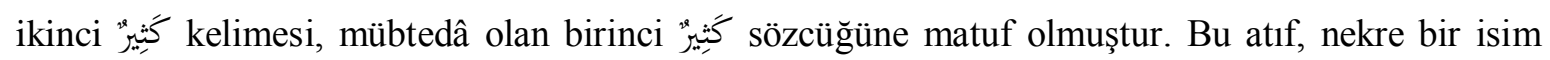
olan ikinci عَثِيْ kelimesinin de mübtedâ olarak gelmesini caiz k1lmıştır.

\subsection{Nekre, Bir Nefi Edatından Sonra Geldiğinde}

Nefi edatından sonra gelen nekre de mübtedâ olabilir. Kur'ân'da buna dair çok sayıda

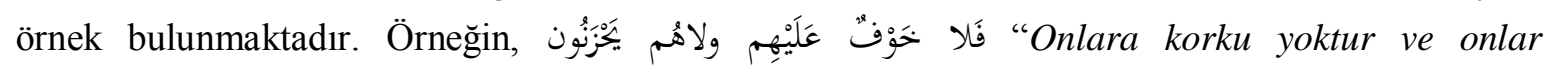

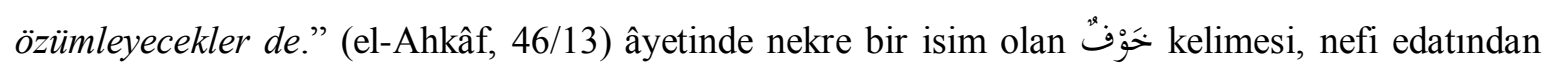
sonra geldiği için mübtedâ olması hususunda herhangi bir mahzur bulunmamaktadır.

\section{Turkish Studies - Language and Literature}

Volume 14 Issue 4, 2019 


\subsection{Nekre, Bir İstifham Edatından Sonra geldiğinde}

İstifham edatından sonra gelen nekrenin de mübtedâ olması caizdir. Kur'ân'da buna dair

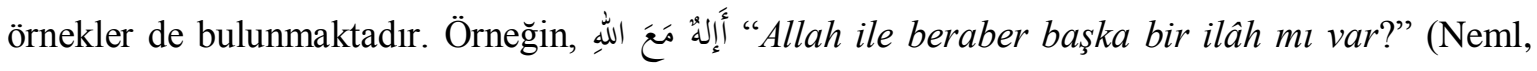
27/60) âyetinde istifham edatından sonra gelen"ٌإٌ lafzı, nekre bir isim olmakla birlikte mübtedâ olmuştur. Bu kelimenin istifham edatından sonra gelmiş olması, onun mübtedâ olmasını caiz kılan sebep olmuştur.

\subsection{Nekre, lٕٕذا el-Fücâiyeden Sonra Geldiğinde}

إذٍ el-fücâiye'den sonra gelen nekre de mübtedâ olabilir. Kur'ân'da buna dair örnekler de mevcuttur. Örneğin, إذا فَريقُ مِنْكُم بِرَبِّمِ يُشُشْكِكُونَ "Bir de bakarsınız, içinizden bir kısmı Rablerine ortak koşar." (en-Nehl, 16/54) âyetinde nekre bir isim olan فَرِقُ kelimesinin, إذِا el-fücâiyye'den sonra gelmesi, onun mübtedâ olmasını caiz kılmıştır.

\subsection{Nekre, Vâv' (واو)u'l-Hâliyyeden Sonra Geldiğinde}

Vâvu'l-hâliyyeden sonra gelen nekre de mübtedâ olarak gelebilir. Kur'ân'da buna dair

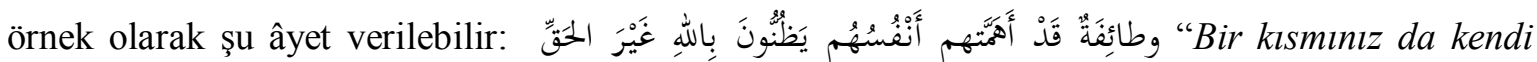
canlarının kaygısına düşmüştü. Allah'a karşı cahiliye zannı gibi gerçek dışı zanda bulunuyorlar..." (Âl-i İmrân, 3/154). Nitekim bu âyette طُائَفَّ kelimesi, nekre bir isim olmakla birlikte vâvu'1hâliyyeden sonra gelmiş olması, onun mübtedâ olmasını caiz kılmıştır.

\subsection{Nekre, لَ'dan sonra Geldiğinde}

Ṿ̛̆'dan sonra gelen nekrenin de mübtedâ olarak gelmesi caizdir. Kur'ân'da buna da dair

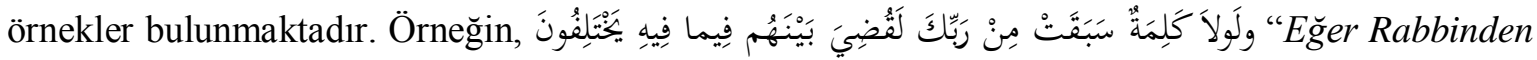
bir söz geçmiş olmasayd, ayrllı̆a düştükleri hususlarda aralarında derhal hüküm verilirdi."

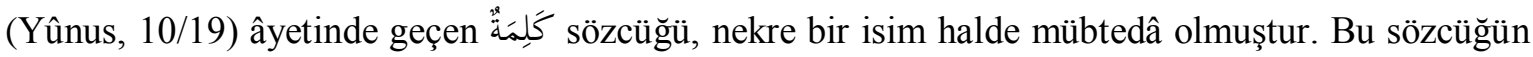
mübtedâ olarak gelmesini caiz kılan sebep ise onun لوَ'dan sonra gelmiş olmasıdır.

\subsection{Nekre, Zarf Olan Haberinden Sonra Geldiğinde}

Haberi mukaddem bir zarf olan nekre de mübtedâ olarak gelebilir. Kur'ân' da buna dair çok sayıda örnek bulunmaktadır. Örneğin, فوفَقَ كُلِّ ذِي عِلْمِ عَلِيمِ "Her ilim sahibinin üstünde daha iyi bir bilen vardır." (Yûsuf, 12/76) âyetinde nekre bir isim olan عَلِيمُ عelimesi mübtedâ olmuştur. Bu nekrenin zarf olan haberinden sonra gelmiş olması, onun mübtedâ olmasını caiz kılmıştır.

\subsection{Nekre, Car ve Mecrûr Olan Haberinden Sonra Geldiğinde}

Haberi mukaddem car ve mecrûrdan oluşan nekrenin de mübtedâ olarak gelmesi caizdir. Kur'ân'da bu kısma da dair çok sayıda örnek mevcuttur. Örneğin, وعَلَى أَبْصارِهِم غِشَاوَة 'Gözleri üzerinde de bir perde vardır...." (el-Bakara, 2/7) âyetinde غِشَاوةٌ kelimesi nekre bir isim olmakla 
birlikte mübtedâ olmuştur. Bu nekrenin car ve mecrûrdan oluşan haberinden sonra gelmiş olması, onun mübtedâ olarak gelmesini caiz kılan sebep olmuştur.

\subsection{Nekre, Şart Edatı Olduğunda}

Nekre, şart ismi olduğunda onun mübtedâ olarak gelmesi caizdir. Kur'ân'da buna da dair

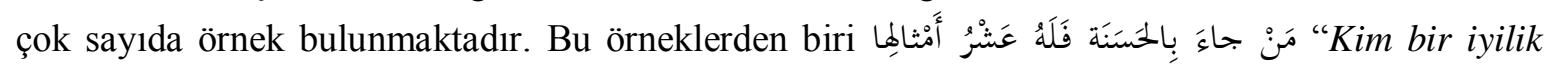

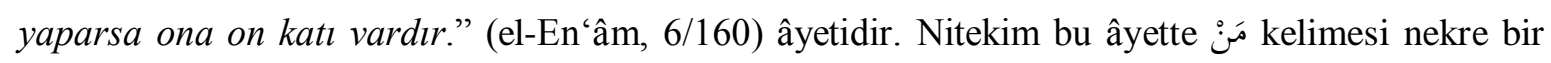
isim olmakla birlikte mübtedâ olmuştur. Bu kelimenin şart bildiren bir isim olması, onun mübtedâ olarak gelmesini caiz kılmıştır.

\subsection{Nekre, Muzaf Bir İsim Olduğunda}

Muzaf olan nekrenin de mübtedâ olarak gelmesi caizdir. Kur'ân'da buna da dair çok sayıda

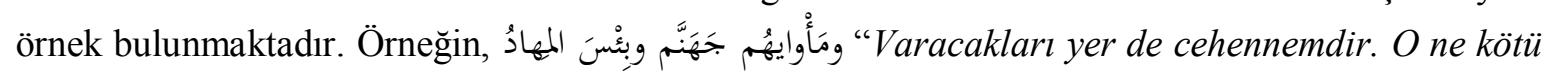
yataktır!.” (er-Ra'd, 13/18) âyetinde nekre bir isim olan مَأْوَي kelimesi mübtedâ olmuştur. Bu kelime kendisine bitişen zamire muzaf olduğundan dolayı, mübtedâ olarak gelmesi caiz olmuştur.

\subsection{Nekre, Taaccüp Anlamını Bildiren Bir Kelime Olduğunda}

Taaccüp anlamını bildiren nekre isim demübtedâ olabilir. Kur'ân'da buna dair örnek olarak da Abes Sûresinde geçen قُتِّلَ الإنسانُ ما أَكْفَرَه "Kahrolası (inkarcı) insan! Ne nankördür o!” (el'Abes, 80/17) âyeti verilebilir. Nitekim bu âyette geçen L sözcüğü, nekre bir isim olup taaccüp bildiren bir kelimedir. Bu âyette L 'nın taaccüp bildiren bir kelime olması, onun mübtedâ olmasını caiz kılan sebep olmuştur.

\section{Sonuç}

İsim cümlesinin temel unsurlarından biri olan mübtedâ, dilciler tarafından birbirinden farklı şekillerde tarif edilmiştir. Sîbeveyhi tarafindan "bir ifadenin üzerine bina edilmesi için kendisiyle başlatılan isim" olarak tarif edilen mübtedâ'nın cümledeki görevi, müsnedün ileyh ve mahkumun aleyh yani kendisi hakkında hüküm verilen ve yargida bulunan unsurdur. Bu nedenle onun ma 'rife olması gerekir. Fakat bazı sebeplerle mübtedâ bazen nekre olarak da gelebilir. Nahiv kaynaklarında geçen bu sebeplere dikkat edildiğinde onlardan bir kısmı doğrudan nekre olan mübtedâyla ilişkili iken, onlardan bir kısmı mübtedâ'dan önce geçen kelimelerle bağlantılı, diğer kısmı ise ondan sonra gelen sözcüklerle alakalı olduğu görülmektedir. Bazı nahiv kaynaklarında müsevvigatu'libtidâi bi'n-nekre olarak ifade edilen bu sebepler, gerek sayıları gerekse ifade ettikleri anlam açısından nahiv âlimleri arasında ihtilaf mahalli olmuşlardır. Aralarında Sîbeveyhi ve İbn Sarrâc'ın da bulunduğu mütekaddimun olan âlimler, mübtedâ'nın nekre olabilmesi için fayda vermesi koşulu dışında her hangi bir şart koşmadıkları gibi, onun hangi durumlarda fayda verebileceği hususunda da herhangi bir bilgi vermemişlerdir. Kaynaklarda müteahhirun olarak geçen âlimler ise, bu sebeplerle ilgili her ne kadar geniş bilgiler vermiş iseler de söz konusu sebeplerin sayısı hususunda ittifak etmemişlerdir. Nitekim onlardan bazıları, bu sebepleri umum ve husus ile ifade edilen iki ana sebebe hasrederken, onlardan çoğu ise söz konusu sebepleri belli sayılarla ifade etmişlerdir. Örneğin İbn Mâlik bu sebeplerin sayısını altı, İbn Hişâm on, Sabbân on beş, İbn 'Akil yirmi dört, Ebû Hayyân yirmi yedi, Suyûtî otuz bir, İbnü’n-Nehhâs otuz iki, el-‘Unnabî ise, kırk iki olarak vermiştir.

Kur'ân'da geçen söz konusu sebeplere gelince, mübtedâ'nın nekre olarak gelmesini caiz kılan sebeplerden sadece belli bir kısmının Kur'ân'da geçtiği görülmektedir. Kur'ân'da onlardan

\section{Turkish Studies - Language and Literature}

Volume 14 Issue 4, 2019 
tespit edilen bazı sebepler şunlardır: Nekre, bir sıfatla mevsuf olan, amel eden, dua anlamında olan, umum bildiren, tafsil amaciyla gelen, mukadder bir soruya cevap olan bir kelime olduğunda. Ayrica nekre, nefi ve istifham edatlarından sonra gelen veya zarf, car ve mecrûr olan haberinden sonra gelen bir kelime olduğunda.

\section{KAYNAKÇA}

Cebbûrî, Sirrî Tâhir. (2010). Müsevvigatu'l-ibtidâi bi'n-Nekire fi'l-Kur'âni'l-Kerîm, Bağdat Üniversitesi İslami İlimler Fakültesi Dergisi.

Cevherî, Ebû Nasr İsmâîl b. Hammâd el-Fârâbî. (1987).es-Sihâh Tâcu'l-Luga ve Sihâhu'l'Arabiyye, thk. Ahmed 'Abdugafûr 'Attâr, Dâru'l-'Illm li’L-Melâyîn, IV. Baskı, Beyrut.

Cezûlî, Ebû Mûsâ Îsâ b. 'Abdilazîz b. Yelelbaht. (t.y.). el-Mukaddimetu'l-Cezûliyye fî'n-Nahv, thk. Şa ‘bân 'Abdulvahhâb Muhammed, nşr. Matba'atu Ümmi'l-Kurâ, Mekke.

Cürcânî, Ebû'l-Hasan'Alî b. Muhammed b. 'Alî es-Seyyid Şerîf. (1983). et-Ta 'rîfât, Dâru'lKutubi'l-‘'̇lmiyye, I. Bask1, Beyrut..

Dimâmeynî, Bedruddîn Muhammed b. Ebî Bekr b. 'Umer. (1983). Ta 'lîku'l-Ferâid 'alâ Teshîl'lFevâid, thk. Muhammed b. 'Abdirrahmân b. Muhammed, I. Bask1, (y.y.)

Ebû Hayyân, Muhammed b. Yûsuf b. 'Alî b. Hayyân el-Endelusî. (t.y.). et-Tezyîl ve't-Tekmîl fî̀ Şerhi Kitâbi ’t-Teshîl, thk, Hasan Handavî, Dâru'l-Kalem, Dımaşk.

(1998). Irtişâfu'd-Dareb min Lisâni'l-'Arab, thk. Receb 'Usmân Muhammed, Mektebetu'l-Hancî, Kahire.

El-Üşmûnî, Ebû Hasan Nûruddîn 'Alî b. Muhammed. (1998). Şerhu'l-Üşmûnî alâ Elfiyyeti İbn Mâlik, Dâru'l-Kutubi'l-‘İlmiyye, I. Baskı, Beyrut.

İbn 'Akîl, 'Abdullâh b. 'Abdirrâhmân el-“Akîlî el-Misrî. (1383). Şerhu İbn 'Akîl 'alâ Elfiyeti İbn Mâlik, thk. Muhyuddîn 'Abdulhamîd, Dâru’t-Turâs, XX. Bask1, Kahire.

İbn Hişâm, Ebû Muhammed 'Abdullâh Cemâlüddîn. (1383). Şerhu Katri'n-Nedâ ve Belli's-Sadâ, thk. Muhammed Muhyuddîn 'Abdulhamîd, II. Bask1, Kahire.

,, (1985). Muğnî'l-Lebîb 'an Kutubi'l-'E'ârib, thk. Mâzin el-Mubârek/Muhammed 'Alî Hamdullâh, Dâru'l-Fikr, VI. Baskı, Dımaşk.

,(t.y.). Evdahu'l-Mesâlik ilâ Elfiyyeti İbn Mâlik, thk. Yûsuf Muhammed el-Bukâ‘̂̂, Dâru'lFikr, (y.y.).

İbn Kâsım El-Murâdî, Ebû Muhammed Bedruddîn Hasan. (2008). Tevdîhu'l-Makâsidi ve'lMesâliki bi Şerhi el-Fiyyeti İbn Mâlik, thk. 'Abdurrahmân 'Alî Süleymân, Dâru'l-Fikri'1'Arabî, I. Baskı, (y.y.).

İbn Mâlik, Ebû 'Abdillâh Cemâlüddîn Muhammed. (1990). Şerhu Teshîli'l-Fevâid, thk. 'Abdurrahmân es-Seyyid ve Muhammed Bedevî, Hecer li’t-Tibâ'a, I. Bask1, (y.y.).

......., (t.y.). Elfiyyetu İbn Mâlik, Dâru't-Ta'âvun, (y.y.).

.......,(t.y.). Şerhu'l-Kâfiyeti'ş-Şâfiyye, thk. 'Abdulmunim Ahmed Hureydî, nşr. Câmi'atu Ümmi'lKurâ, Mekke.

İbn Manzûr, Ebû'l-Fadl Muhammed b. Mukerrem el-Ensârî. (1414). Lisânu'l- 'Arab, Dâru Sadır, III. Bask1, Beyrut. 
İbn Serrâc, Ebû Bekr Muhammed b. es-Sirrî b. Sehl en-Nahvî. (t.y.). el-Usûl fín'n-Nahv, thk. 'Abulhuseyn el-Fetlî, Muessesetu'r-Risâle, Beyrut.

İbn Yaîş, Ebû'l-Bekâ Muvaffakuddîn Yaîş b. 'Alî. (2001). Şerhu'l-Mufassal, Dâru'l-Kutubi’l'İlmiyye, I. Baskı, Beyrut.

İbnü'l-Hâcib, Cemâlüddîn b. 'Usmân b. 'Amr b. Ebî Bekr el-Esnevî. (2010). el-Kâfiyye fí İlmi'nNahv, thk. Sâlih 'Abdulazîm, Mektebetu'l-Âdâb, I. Bask1, Kahire.

, (t.y.). el-Îdâh fî Şerhi'l-Mufassal, thk. Mûsâ Benâyî el-'Alîlî, İhyâu't-Turasi'l-'Arabî, Bağdat.

İbnü’nahhâs, Ebû 'Abdillâh Bahâüddîn Muhammed b. İbrâhîm. (2004). et-Ta 'lîka 'ala'l-Mukarrab, thk. Cemîl ‘Abdullâh 'Uveyde, Vizâretu's-Sakâfe, Ürdün.

Mekûdî, Ebû Zeyd 'Abdurrahmân b. 'Alî b. Sâlih. (2005). Şerhu'l-Mekûdî 'ala'l-Elfiyye li İbn Mâlik, thk. 'Abdulhamîd Hindâvî, el-Mektebetu'l-'Asriyye, Beyrut.

Nâziru'l-Ceyş, Muhibuddîn Muhammed b. Ahmed, el-Halebî. (1428). Temhîdu'l-Kavâ 'id bi Şerhi Teshîli'l-Fevâid, thk. 'Alî Muhammed Fâhir, Dâru's-Selâm, I. Baskı, Kahire.

Radî, Muhammed b. Hasan el-İstirâbâzî. (1996). Şerhu'l-Kâfiye li İbn Hâcib, thk. Hasan b. Muhammed b. İbrâhîm el-Hifzî, nşr. Câmi'atu'l-İmâm Muhammed b. Su'ûd el-İslâmiyye, Suudi Arabistan.

Râzî, Ebû ‘Abdillâh Zeynuddîn Muhammed b. Ebî Bekr b. 'Abdilkâdir. (1999). Muhtâru's-Sihâh, thk. Yûsuf eş-Şeyh Muhammed, el-Mektebetu'l-'Asriyye, V. Bask1, Beyrut.

Sabbân, Ebû'l-‘İrfân Muhammed b. 'Alî. (1997). Hâşiyetu's-Sabbân 'alâ Şerhi'l-Eşmûnî li Elfiyyeti İbn Mâlik, Dârul-Kutubi'l-'İlmiyye, Beyrut.

Sîbeveyhi, Ebû Bişr 'Amr b. 'Usmân el-Hârisî. (1988). el-Kitâb, thk., Abdusselâm Muhammed Hârun, Mektebetu'l-Hâncî, III. Baskı, Kahire.

Suyûtî, Celâlüddîn 'Abdurrahmân b. Ebî Bekr. (t.y.). Hem 'u'l-Hevâmi' fí Şerhi Cem 'i'l-Cevâmi', thk. 'Abdulhamîd Handâvî, el-Mektebetu't-Tevkîfiyye, Misır.

...........,(t.y.). el-Eşbâhu ve'n-Nezâir fì'n-Nehv, thk. Gazi Muhtar Tuleymât, Mecme‘u'l-Lugati'l'Arabiyye, Dımaşk.

Süheylî, Ebü’l-Kâsım 'Abdurrahmân b. 'Abdillâh. (1992). Netâicu'l-Fikri fi'n-Nahv, Dâru'lKutubi’l-'İlmiyye, Beyrut.

Tekin, Ahmet. (2018). Kur'ân'ın Dilbilimsel Yönü, İlahiyat Yayınları Ankara.

'Unnâbî, Ebü'l-'Abbâs Ahmed b. Muhammed. 'Alî. (t.y.). et-Tezkire fî Tesviğì'l-İbtidâi bi'nNekire, thk. Hâdî Ahmed Ferhân eş-Şüceyrî, Mecelletü'l-'Ulûmi’l-İslâmiyye, Sayı, 12, s. 335.

Vakkâd, Hâlid b. 'Abdillâh el-Ezherî. (2000). Şerhu't-Tasrîh 'ala't-Tavdîh, Dâru'l-Kutubi'l'İlmiyye, Beyrut.

Yâsîr El-Harûb. (2010). Dirâsetün Cedîdetün fî Kadiyeti'l-íbtidâi bi’n-Nekire, Mecelletu Câmi'ati el-Halîl li’1-Buhûs, Cilt, V, Sayı, I, s. 99-122.

Zemahşerî, Ebû'l-Kâsım Mahmûd b. 'Amr b. Ahmed. (1993). el-Mufassal fî San 'ati'l-İ'râb, thk. 'Alî b. Mulham, Mektebetu'l-Hilâl, I. Bask1, Beyrut.

Suzan, Yahya. (2001). Kur'ân'da İstifhâm Üslûbu, (Basılmamış Yüksek Lisans Tezi), Diyarbakır.

\section{Turkish Studies - Language and Literature}

Volume 14 Issue 4, 2019 